DOI 10.31558/2307-2318.2019.1.10

УДК 658.8.013

Таранич А.В., к. е. н., доцент, доцент кафедри маркетингу, Донецький національний університет імені Василя Стуса

Шаповал А.С., бакалавр освітньої програми «Маркетинг», Донецький національний університет імені Василя Стуса

\title{
ОСОБЛИВОСТІ БРЕНДИНГОВОЇ ПОЛІТИКИ СПОЖИВЧИХ
}

\section{TOBAPIB}

В роботі розглянуто теоретичні основи побудови брендингової політики споживчих товарів, іï елементи (дистрибуція, мерчандайзинг), зв'язок із комплексом маркетингу підприємства, обгрунтовано заходи візуального мерчандайзингу, на прикладі ринку пива України розраховано індекси сприйняття споживачами різних кольорів етикеток.

Мета роботи - визначити особливості брендингової політики споживчих товарів,

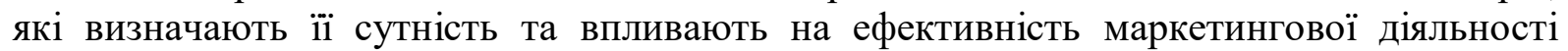
підприємств на ринку.

Визначено, що брендингова політика підприємств потребує докладної класифікації відносно власного місця як в комплексі маркетингового міксу, так і в загальних процесах управління маркетинговою діяльністю за визначенням, набором інструментів, зв'язком із стратегіями сегментування ринку, позиціювання продукції, дистанціювання бренду від конкурентів, входженням портфелю брендів до портфелю стратегічних бізнес-одиниць підприємства.

Доведено, що брендингова політика споживчих товарів складається 3 частин, перша з яких за жодних технологічних, економічних і соціальних умов розвитку ринку не повинна змінюватись (точка позиціювання бренду на споживчому ринку); а друга частина повинна постійно трансформуватись як зворотна реакція на дії конкурентів і зміни макроекономічних чинників зовнішнього середовища (методи диференціації бренду від конкурентів).

Визначено, що критерієм ефективності брендингової політики споживчих товарів є охоплення збутової мережі та наявність певного бренду в роздрібних точках продажу. На прикладі кольору етикеток та в залежності від структурних зрушень на ринку пива України визначено індекси популярності кольорів етикеток: помаранчевий, зелений, білий, чорний, червоний i синій (наведено за зниженням продажів), які можна використовувати при проведенні ребрендингу чи формування брендингової політики споживчих товарів для продуктових ринків.

Ключові слова: бренд, торгова марка, маркетинг, брендингова політика, позиціювання, товарна диференціація, конкурентна диференціація, дистрибуція, візуальний мерчандайзинг, охоплення збутових мереж.

\section{Таранич А.В., Шаповал А.С. ОСОБЕННОСТИ БРЕНДИНГОВОЙ ПОЛИТИКИ ПОТРЕБИТЕЛЬСКИХ ТОВАРОВ}

В работе рассмотрены теоретические основы построения брендинговой политики потребительских товаров, ее элементы (дистрибуция, мерчандайзинг), связь с комплексом маркетинга предприятия, обоснованы мероприятия визуального мерчандайзинга, на примере рынка пива Украины рассчитаны индексы восприятия потребителями разных цветов этикеток. 
Цель работы - определить особенности брендинговой политики потребительских товаров, которые определяют ее сущность и влияние на эффективность маркетинговой деятельности предприятий на рынке.

Доведено, что брендинговая политика предприятий требует подробной классификации относительно собственного места как в комплексе маркетингового микса, так и в общих процессах управления маркетинговой деятельностью по определению, набору инструментов, связью со стратегиями сегментирования рынка, позиционирования продукции, дистанцирования бренда от конкурентов, вхождения портфеля брендов в портфель стратегических бизнес-единиц предприятия.

Доказано, что брендинговая политика потребительских товаров состоит из частей, первая из которых ни при каких технологических, экономических и социальных условий развития рынка не должна изменяться (точка позиционирование бренда на потребительском рынке); а вторая часть должна постоянно трансформироваться как обратная реакция на действия конкурентов и изменения макроэкономических факторов внешней среды (методы дифференциации бренда от конкурентов).

Определено, что критерием эффективности брендинговой политики потребительских товаров является охват сбытовой сети и наличие определенного бренда в розничных точках продаж. На примере цвета этикеток и в зависимости от структурных сдвигов на рынке пива Украины определены индексы популярности цветов этикеток: оранжевый, зеленый, белый, черный, красный и синий (приведены по снижению объемов продаж), которые можно использовать при проведении ребрендинга или формирования брендинговой политики потребительских товаров для продуктовых рынков.

Ключевые слова: бренд, торговая марка, маркетинг, брендинговая политика, позиционирование, товарная дифференциация, конкурентная дифференциация, дистрибуция, визуальный мерчандайзинг, охват сбытовых сетей.

\section{Taranych A., Shapoval A.}

\section{PECULIARITIES OF CONSUMER PRODUCTS BRANDING POLICY}

The paper deals with the theoretical basis of building a branding policy of consumer goods, its elements (distribution, merchandising), the relationship with the complex marketing enterprise, justified visual merchandising activities, on the example of the beer market of Ukraine calculated consumer perception indices of different colors of labels.

The purpose of the work is to determine the features of the branding policy of consumer goods, which determine its essence and impact on the effectiveness of marketing activities of enterprises in the market.

It is brought that the branding policy of enterprises requires a detailed classification of their own place in the complex of the marketing mix, as well as in the General processes of marketing management to determine a set of tools, communication with the strategies of market segmentation, product positioning, brand distancing from competitors, entering the portfolio of brands in the portfolio of strategic business units of the enterprise.

It is proved that the branding policy of consumer goods consists of parts, the first of which under any technological, economic and social conditions of market development should not change (the point of brand positioning in the consumer market); and the second part should be constantly transformed as an inverse reaction to the actions of competitors and changes in macroeconomic factors of the environment (methods of differentiation of the brand from competitors). 
It is determined that the criterion of efficiency of branding policy of consumer goods is the coverage of the sales network and the presence of a certain brand in retail outlets. On the example of label color and depending on the structural changes in the beer market of Ukraine, the indices of label colors popularity are determined: orange, green, white, black, red and blue (shown by sales volume reduction), which can be used for rebranding or formation of consumer goods branding policy for food markets.

Keywords: brand, trademark, marketing, branding policy, positioning, product differentiation, competitive differentiation, distribution, visual merchandising, coverage of distribution networks.

Постановка проблеми. Сучасна світова економіка розвивається як глобальна й інформаційна (мережева), що змушує кожен окремий товар на певному національному ринку перебувати на окремій стадії життєвого циклу. Така глобальна конкуренція спрямовує зусилля виробників до різновекторного коригування власних життєвих циклів та потребує єдиної точки відліку для синхронізації дій. Зазначена ситуація характеризується терміном «глокалізація» (глобальна локалізація) та принципом управління «думай глобально, дій локально» [1].

Поєднанням цілей регіонального й клієнтоорієнтованого розвитку компаній $\epsilon$ їх брендингова політика, що поєднує життєвий цикл товару та глобальну споживчу задоволеність. Глобальна брендингова політика дозволяє виробникам згладжувати наслідки локальних «збутових криз» через фінансові, політичні, соціально-економічні чинники шляхом збереження лояльності цільових аудиторій і ринків збуту.

Разом із зазначеними факторами, слід зауважити, що окремою сферою дослідження брендингової політики є питання іiї фінансового вимірювання та впливу на ринкову вартість підприємства, а також співвідношення 3 маркетинговою політикою: складова товарної політики (частина i ціле) чи самостійна наукова концепція (альтернативний напрямок). Таким чином, у сучасній практиці брендингова політика має споживчі та фінансові аспекти вимірювання, що зумовлює потребу сталого методологічного підходу до ії визначення, класифікації та дослідження.

Аналіз останніх досліджень і публікацій. Базові аспекти брендингової політики щодо генезису, еволюції та визначення торгових марок і брендів достатньо широко розкриті в роботах «класиків» маркетингу: Ф. Котлера, Т. Левіта, Дж. МакКарті, П. Друкера, Дж. Еванса, Б. Бермана, Ж.-Ж. Ламбена, Б.Карлоффа, А.Куса, М. Портера, Х. Хершгена, Е. Діхтля, П.Дойля. Також в цьому контексті слід зазначити роботи видатних науковців пострадянського простору: Г. Абрамішвілі, Д.Костюхін, А. Романов, П. Зав'ялов, В.Демідов, Г. Багієв, Е. Голубков, Ф. Новіков, Е. Уткін; а також українських дослідників: А. Павленко, А. Войчак, В.Кардаш, С.Гаркавенко, І. Решетнікова, А. Старостіна, О. Зозульов, С. Ілляшенко, В. Заруба, Л. Мельник, Є. Крикавський, О.Телетов, О. Азарян, М.Окландер, Л. Балабанова тощо.

3 практичної точки зору брендингова політика як стратегія позиціювання продукції розкрита в публікаціях Дж. Траута, Е. Райса, С. Ривкіна, Д. Аакера, К. Келлера, Дж. Сондерса, Ж.-Н. Капферера, Т. Геда, М. Саатчі тощо.

Постановка завдання. В теперішній час питання щодо сутності, складових елементів i інструментів маркетингу щодо формування брендингової політики підприємств перебуває в стадії теоретичних досліджень й апробації результатів для визначення умов, за якими певні інструменти маркетингу / брендингу / мерчандайзингу будуть адаптовані для споживчих, високотехнологічних, промислових й інших категорій товарів. 
Мета роботи - визначити особливості брендингової політики споживчих товарів, які визначають іiі сутність та впливають на ефективність маркетингової діяльності підприємств на продуктових ринках.

Виклад основного матеріалу дослідження. Брендингова політика споживчих товарів як економічна категорія спирається на теорію комунікацій, реклами та маркетингу, як це наведено на рисунку 1, де поєднуються такі базові теоретичні категорії, як «сутність» бренду, його «індивідуальність», «атрибути» й «імідж», із синтетичними поняттями «позиціювання» та «диференціація», що визначають комплекс маркетингу підприємства. Розглянемо їх більш детально.

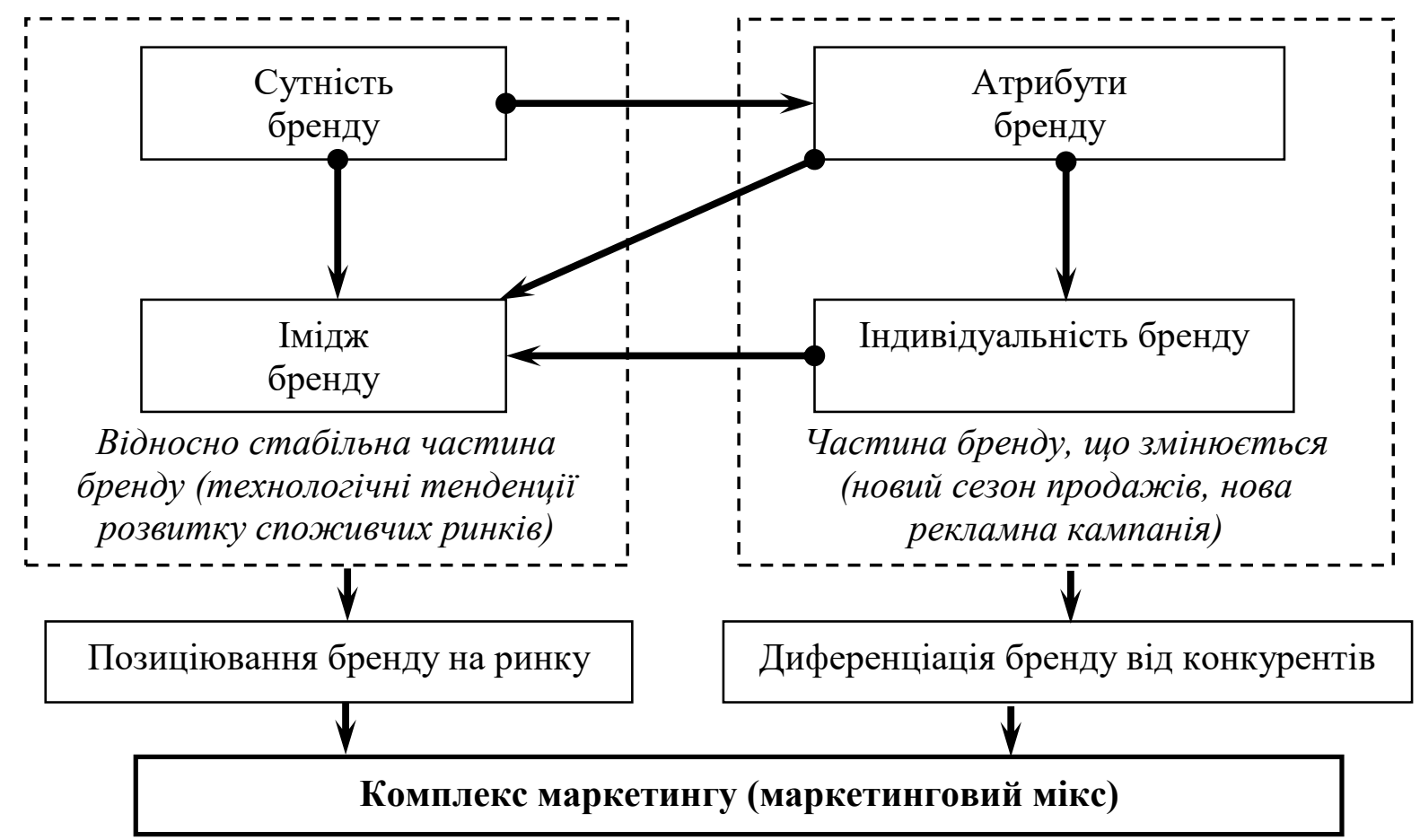

\section{Рисунок 1 - Складові елементи брендингової політики споживчих товарів та її зв'язок із комплексом маркетингу підприємства}

Сутністю бренду є головна риса, яка відображає його ринкове призначення: те, що задовольняє потреби споживачів, те, що мотивує покупців до придбання певних товарів. Атрибути бренду формуються його технологічними елементами та визначають певні функціональні й емоційні асоціації (позитивні чи негативні) покупців і потенційних клієнтів. Вони мають різну силу і важливість для різних сегментів ринку. Індивідуальність бренду є сукупністю всіх атрибутів бренду, яка одночасно відображає погляд на бренд і є миттєвою обіцянкою споживачам від авторів бренду. Імідж бренду - це унікальний набір асоціацій, думок покупців, який виступає довгостроковою обіцянкою споживачам від авторів бренду.

Важливим кроком формування брендингової політики підприємства на споживчому ринку є координація між стабільною та змінною частинами, яка в довгостроковій перспективі повинна забезпечувати зв'язок потреб споживачів із іміджом і позиціюванням бренду на ринку. Така синхронізація відбувається за рахунок новацій (технологічних, дизайнерських), рекламних акцентів на соціальних зрушеннях, впливу на свідомість споживачів (PR, спонсорінг, product placement). 
Для продуктових ринків (FMCG) першим елементом брендингової (маркетингової) політики є охоплення збутових мереж, яке за законом значних чисел визначає її ефективність: незалежно від маркетингового позиціювання, дистанціювання від конкурентів, інтенсивності рекламного навантаження на споживачів збут споживчих товарів залежить від наявності їх в роздрібних торговельних мережах.

Другим елементом брендингової політики споживчих товарів $\epsilon$ мерчандайзинг як стратегія та тактика торгівельного маркетингу. До стратегічних рішень брендингової політики в сфері мерчандайзингу відноситься територіальна щільність покриття збутових мереж відповідно до економічного районування міст й інтенсивності споживчих потоків. Тактика мерчандайзингу коливається від керування потоками споживачів певної торгівельної зали до впливу на природну систему уваги окремих споживачів при їх просуванні торгівельним маршрутом між відділами та вздовж полиць торгівельної зали. В останньому випадку у складі елементів брендингової політики споживчих товарів відзначають аромомаркетинг, нейромаркетинг, візуальний мерчандайзинг, штучна зміна простору торгівельної зали («острови» 3 товарами, внутрішні вітрини), семплінгові заходи [2].

Розглянемо більш детально заходи брендингової політики споживчих товарів на прикладі візуального мерчандайзингу.

Взагалі поняття «візуальний мерчандайзинг» означає комплекс заходів, спрямованих на підвищення уваги покупців до товару, забезпечення ефективності його презентації у місцях продажу шляхом оформлення вивісок і вітрин, дизайн приміщення, підбір відповідного торговельного обладнання, комбінування природнього із системами штучного освітлення, використання інформаційно-рекламних носіїв, зонування торгівельних зал тощо.

Консультант з маркетингу Мартін Ліндстром стверджує, що саме музика, запахи та вдале поєднання кольорів допомагають виробити у людей умовний рефлекс, який пов'язаний 3 виникненням сталих асоціацій щодо певного бренду. Також дослідник впевнений, що в конкурентній боротьбі за лояльність споживача перемогу отримає той, хто буде ефективно використовувати всі п'ять органів чуття людини і досягне оптимального поєднання різних маркетингових інструментів.

До інструментів візуального мерчандайзингу, що створюють атмосферу схильності покупців до комфортного перебування / пересування торгівельною залою й ознайомлення з товарами, можна віднести такі психологічні прийоми:

1) «фігура на фоні» - висвітлення певного товару на фоні інших, тим самим людина одразу виділяє з оточення один об'єкт, а інші товари на деякий час стають фоном для нього;

2) «на рівні очей» розкладають товар, який потрібно найшвидше продати;

3) «мертва зона» - часто залишаються без уваги покупця всі предмети, які знаходяться на нижніх полицях, особливо в нижньому лівому куті. Тому там потрібно розташовувати товари у великих упаковках та товарний запас, також доречним буде товар, який має цілеспрямований попит;

4) «перемикання уваги» - не можна розкладати однотипний товар, з однаковою кольоровою гамою, у довгу лінійку без зорових акцентів;

5) «групування» товарів за конкретними ознаками, такими як: ціна, вид товару, розмір або вага упаковки, торгівельні марки тощо;

6) «2/3» - в магазині існує багато відволікаючих факторів, людина може мати обмежений час на розгляд товарів, тому вона не помічає, як пройшла вже половину 
торгівельної зали. Тому центр магазину є оптимальним місцем для розміщення товару, що просувається;

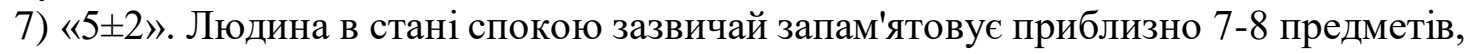
які іï оточують. Але в магазинах ця цифра скорочується до 4-5 товарів. Тому кількість POS-матеріалів не повинна перенавантажувати увагу споживача.

Одним із основних інструментів візуального мерчандайзингу щодо впливу на споживачів є колір (поєднання кольорів), які здатні породжувати почуття (заспокоювати відвідувачів на вході то торгівельної зали; збуджувати увагу до певних товарів). За дослідженнями рекламної корпорації «Young \& Rubicam» було виявлено, що колір має різний ступінь запам'ятовування. За даним показником лідируючу позицію займають жовті та червоні кольори, які найшвидше здатні стимулювати нервову систему та увагу. Їх найдоречніше використовувати в оформленні логотипів, пропозицій (цінників) та реклами.

Часто при використанні візуального мерчандайзингу виникає проблема з тим, що обраний фірмовий (іміджевий) колір не відповідає цільовому ціновому сегменту ринку, на який орієнтовано брендингову політику підприємства. Адже, представники різних класів можуть сприймати один колір по-різному. Білий, чорний та сірий кольори викликають у свідомості споживача асоціацію з помірністю та солідністю товару. Але якщо, наприклад, таку палітру використати для оформлення продуктового магазину нижнього і середнього цінового сегмента, то більшість споживачів просто не сприйматимуть його як магазин споживчих товарів.

Останнім часом також прослідковується тенденція до зміни корпоративних кольорів. Саме завдяки ребрендингу компанії мають можливість пожвавити сприйняття бренду та змінити свої відносини зі споживачем. Тобто у сегменті ринку, який є перенасиченим, колір допоможе радикально відділиться від конкурентів.

Ще одним вагомим інструментом впливу на покупця є етикетки. Їх вплив на вибір споживача розглянемо на прикладі етикеток для пива. На сьогоднішній день, на українському ринку пива існує велика кількість різноманітних кольорових рішень на пляшках з пивом. Для масового сегмента найчастіше використовуються яскраві кольори і картинки. А ось для елітного продукту навпаки, найкраще підходять стримані кольори і відтінки без зайвого пафосу і пихатості, та мінімалізм у дизайні. Кількість кольорів необхідно зводити до мінімуму, використовуючи до двох-трьох кольорів. Якщо дизайн опрацьовано правильно, то етикетка має виглядати дійсно стильно, стримано i привабливо.

Щоб краще визначити роль кольору етикеток пива у свідомості споживача, потрібно провести детальний аналіз самого ринку. За даними Держкомстату Україні й асоціації виробників «Укрпиво», було визначено, що у період з 2006 до 2017 рр. обсяги виробництва та споживання пива пропорційно зменшувались (рис. 2).

Близько 10 років тому частка трьох провідних компаній досягла свого максимуму, і здавалося, що ринок пива практично повністю знаходиться під їх контролем. Але поступово тенденція консолідації ринку переломилася. Після економічної кризи 2008 року розпочав швидко розвиватися сегмент «живого» пива, який дозволив вижити багатьом середнім підприємствам.

Також, в 2010-2011 рр. відбулись наступні події: вихід на український ринок компанії Efes i створення альянсу компаній «Перша приватна броварня» (далі ППБ) і «Радомишль» під егідою міжнародної інвестиційної компанії Oasis CIS. Крім того, в останні роки почало швидко збільшуватися число малих пивоварень, частка яких поки 
не перевищує 1 \% ринку. Але, як показує зарубіжний досвід, з часом вона теж буде значно зростати.

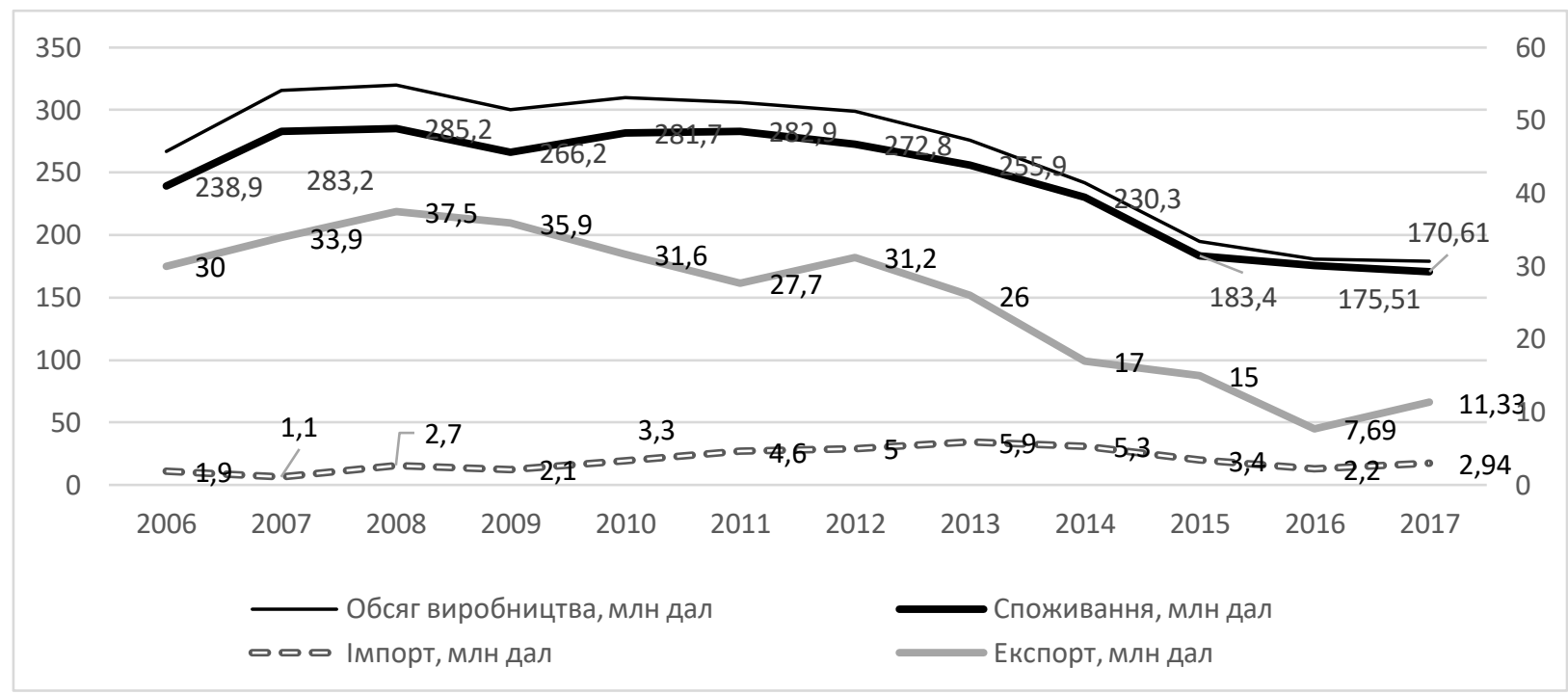

Рисунок 2 - Тенденції розвитку основних показників ринку пива в Україні за період з 2006 до 2017 рр., млн дал [3, 4]

Наслідком всіх цих процесів стало швидке скорочення частки трійки лідерів ринку. Якщо в 2008 році вона становила 92,4\%, в 2013 році - вже 81,4 \%, а в 2017 році знизилась до 73,5 \%. У 2016 році знизилась концентрація продажів лідерів ринку до 71,3\% за рахунок скорочення збуту компаній Оболонь і Ефес (рис 3).

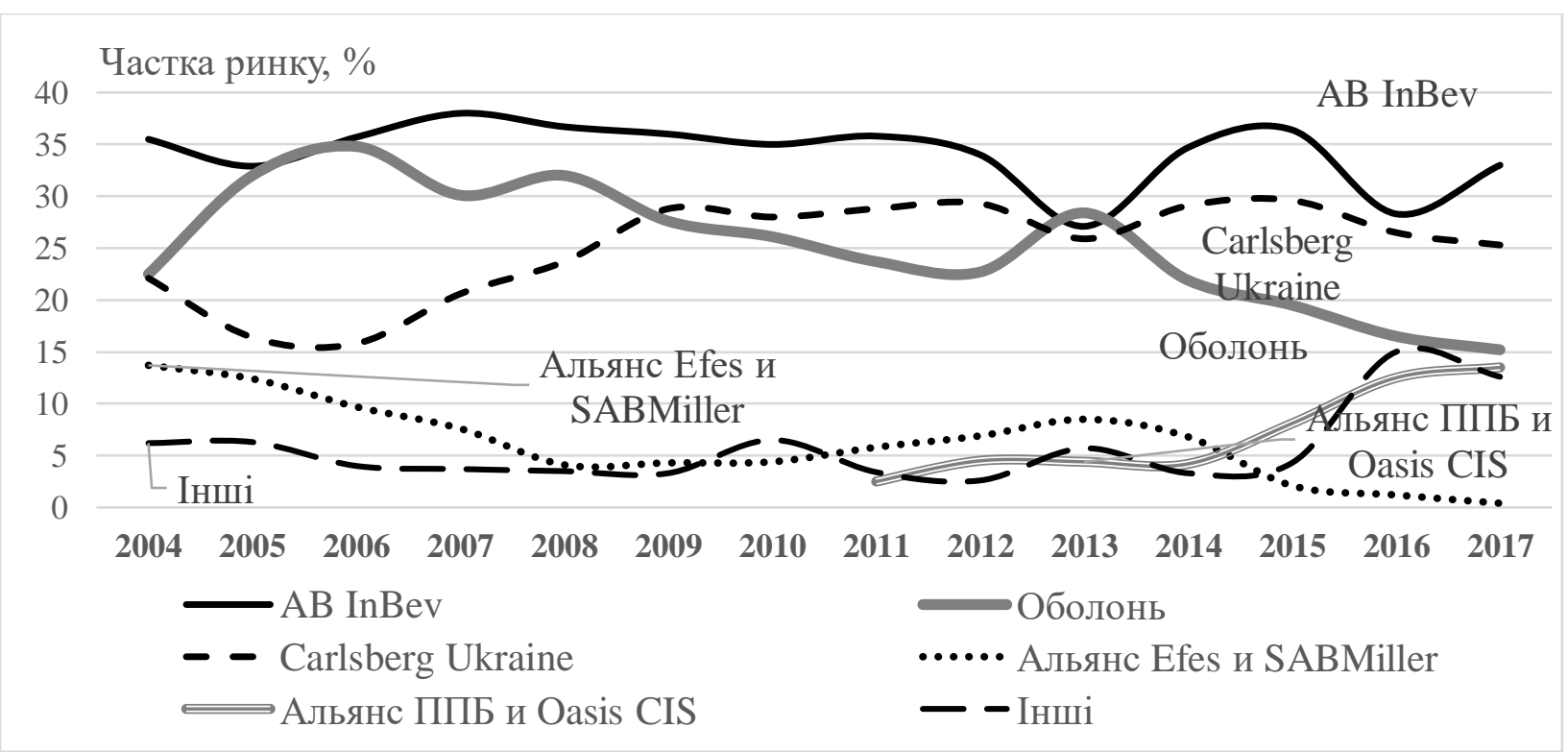

Рисунок 3 - Динаміка зміни ринкових позицій виробників пива в Україні в період

Джерело: власні розрахунки авторів з 2004 по 2017 pp.

На тлі стагнації і подальшого спаду пивоварної галузі в Україні, така втрата ринкових позицій здається ще більш значною. У лідерів падають їх продажі. Щоправда, потрібно відзначити, що лідерам ринку - компаніям Carlsberg Ukraine i AB InBev - поки 
вдається протистояти цьому процесу за рахунок активної маркетингової політики, фінансової підтримки материнських кампаній і витіснення пива Оболонь з 2008 по 2012 і $з 2013$ рр. до теперішнього часу.

Виходячи 3 наведених даних, було розраховано обсяги споживання пива п'яти провідних виробників на ринку (табл. 1).

Таблиця 1

Обсяги споживання пива в Україні за період 32008 до 2017 рр., млн дал

\begin{tabular}{|c|c|c|c|c|c|c|c|c|c|c|}
\hline Компанії & 2008 & 2009 & 2010 & 2011 & 2012 & 2013 & 2014 & 2015 & 2016 & 2017 \\
\hline AB InBev & 104,7 & 95,8 & 98,6 & 101,3 & 92,8 & 69,3 & 79,9 & 66,8 & 49,7 & 56,3 \\
\hline $\begin{array}{l}\text { Carlsberg } \\
\text { Ukraine }\end{array}$ & 67,6 & 76,7 & 78,9 & 81,5 & 79,9 & 66,3 & 67,0 & 54,3 & 46,5 & 43,2 \\
\hline Оболонь & 91,3 & 73,5 & 73,5 & 67,0 & 61,9 & 72,7 & 50,4 & 35,8 & 29,0 & 25,9 \\
\hline $\begin{array}{l}\text { Альянс } \\
\text { ППБ и } \\
\text { Oasis CIS }\end{array}$ & - & - & - & 7,1 & 12,3 & 11,3 & 9,7 & 14,9 & 21,9 & 23,0 \\
\hline $\begin{array}{l}\text { Альянс } \\
\text { Efes и } \\
\text { SABMiller }\end{array}$ & 11,7 & 11,4 & 12,4 & 16,4 & 18,8 & 21,8 & 15,7 & 3,9 & 2,1 & 0,7 \\
\hline Iнші & 10,0 & 8,8 & 18,3 & 9,6 & 7,1 & 14,6 & 7,6 & 7,9 & 26,3 & 21,5 \\
\hline ВСЬОГО & 285,2 & 266,2 & 281,7 & 282,9 & 272,8 & 255,9 & 230,3 & 183,4 & 175,51 & 170,61 \\
\hline
\end{tabular}

Джерело: власні розрахунки авторів

Як ми вже зрозуміли, майже для кожного виду товару має бути підібраний відповідний спектр кольорів. Розглянемо детальніше найбільш популярні кольори, які використовують компанії у дизайні своїх брендів для стимулювання покупця до швидкої покупки (рис. 4).

Tuborg, Carlsberg, Рогань, Білий відмідь, Сармат

Арсенал, Carling, Miller

Рогань, Чернігівське, Zlata Praha, Zatecky Gus

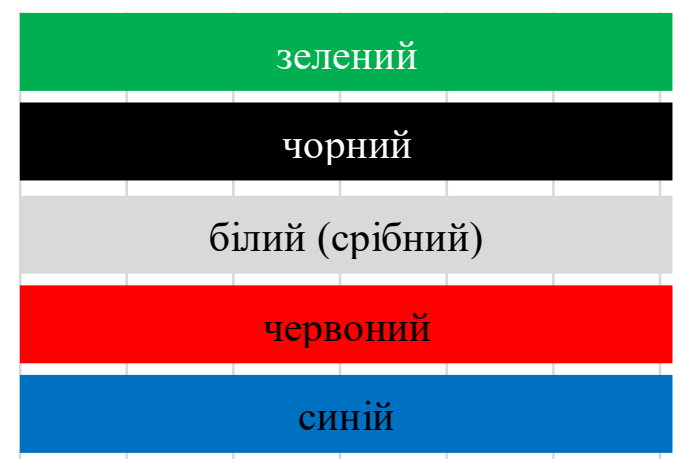

Славутич, Балтика-3, Жигулівське

Янтар, Авторське, Золота бочка, Kozel, Медове

жовтий (помаранчевий, золотий)

\section{Рисунок 4 - Найпопулярніші кольори, які використовуються на етикетках пива}

$[5,6]$

3 рисунка видно, що на пивному ринку представлено 6 найбільш популярних кольорів, серед них є чорний, який $є$ кольором преміум-класу. Також в даному переліку представлений червоний колір, він стимулює нервову систему та увагу покупця, швидше ніж всі інші кольори, але деякі споживачі реагують на цей колір агресивно. У своєму дизайні виробники пива використовують зелений колір, який в багатьох асоціюється 3 природою і ландшафтом та викликає відчуття свіжості та спокою. Останнім часом 
спостерігається тенденція нової ери золотого кольору, який використовують не тільки як додатковий, як раніше, а ще й в якості основного кольору, оскільки він викликає асоціацію стильності.

Кожен з досліджених виробників пива використовує в своїх етикетках майже всі перелічені вище кольори. За проведеними розрахунками щодо кількості використаних кольорів на етикетках (табл. 2), на ринку найбільше представлено сортів із білим або срібним кольорами. I це не дивно, адже вони є кольорами повної відкритості та не викликають жодного неприємного відчуття.

Таблиця 2

\section{Використання кольорів різними виробниками пива в Україні}

\begin{tabular}{|c|c|c|c|c|c|c|c|}
\hline \multirow[b]{2}{*}{ Компанії } & \multicolumn{6}{|c|}{ Кольори, що домінують на етикетках } & \multirow[b]{2}{*}{$\begin{array}{c}\text { Всього } \\
\text { кольорів }\end{array}$} \\
\hline & $\begin{array}{c}\text { Білий } \\
\text { (срібний) }\end{array}$ & Зелений & $\begin{array}{l}\text { Помаранчевий, } \\
\text { жовтий (золотий) }\end{array}$ & Синій & Червоний & Чорний & \\
\hline $\mathrm{AB}$ InBev & 9 & 1 & 5 & 1 & 2 & 2 & 20 \\
\hline $\begin{array}{l}\text { Carlsberg } \\
\text { Ukraine }\end{array}$ & 8 & 3 & 3 & 4 & 1 & 3 & 22 \\
\hline Оболонь & 10 & 1 & 1 & 2 & 1 & 1 & 16 \\
\hline $\begin{array}{c}\text { Альянс } \\
\text { ППБ и } \\
\text { Oasis CIS }\end{array}$ & 3 & - & 5 & & 1 & 2 & 11 \\
\hline $\begin{array}{c}\text { Альянс } \\
\text { Efes и } \\
\text { SABMiller }\end{array}$ & 2 & - & 1 & 2 & 1 & 1 & 7 \\
\hline Разом & 32 & 5 & 15 & 9 & 6 & 9 & 76 \\
\hline
\end{tabular}

Джерело: власні розрахунки авторів

Подальше співставлення даних таблиць 1 і 2 щодо середніх обсягів продажів пива, що припадають на кожний 3 кольорів етикеток, дозволило отримати результати впізнаванності (популярності) за кожним кольором. За відсутності даних про продажі чи ринкову частку кожного сорту/торгівельної марки, позначеної певним кольором, розрахунки проводились за усередненими значеннями: наприклад, компанія AB InBev представлена на ринку 20 кольорами етикеток, за результатами 2017 року на кожний колір припадає 2,8 млн дал продажів тощо. Результати розрахунків за кожним кольором для провідних конкурентів наведено в табл. 3.

Як свідчать проведені розрахунки, кожний з досліджених кольорів має певну привабливість в очах споживачів, що виражається в продажах пива з певним кольором етикеток, з яких помаранчевий, зелений і білий кольори частіше використовуються виробниками для диференціації власної продукції відносно конкурентів. На чорний, червоний і синій кольори припадає менша кількість продажів. 
Таблиця 3

Визначення рівня привабливості кольорів споживчих товарів на прикладі ринку пива України

\begin{tabular}{|l|c|c|c|}
\hline \multicolumn{1}{|c|}{ Колір етикетки } & $\begin{array}{c}\text { Кількість } \\
\text { кольорів }\end{array}$ & $\begin{array}{c}\text { Продаж пива за } \\
\text { кольорами } \\
\text { етикеток, млн дал }\end{array}$ & $\begin{array}{c}\text { Питома } \\
\text { популярність } \\
\text { кольорів }\end{array}$ \\
\hline Помаранчевий, жований (золотий) & 15 & 32,14891 & 2,143261 \\
\hline Зелений & 5 & 10,32191 & 2,064382 \\
\hline Білий & 32 & 63,7 & 1,990625 \\
\hline $\begin{array}{l}\text { Всього / Середній рівень } \\
\text { привабливості }\end{array}$ & 76 & 149,097 & $\mathbf{1 , 9 6 1 8 0 2}$ \\
\hline Чорний & 9 & 17,42216 & 1,935796 \\
\hline Червоний & 6 & 11,40428 & 1,900713 \\
\hline Синій & 9 & 14,0997 & 1,566633 \\
\hline
\end{tabular}

Джерело: власні розрахунки авторів

Висновки. Брендингова політика споживчих товарів має певні особливості, що відрізняють ії від інших товарних груп. По-перше, вона містить частину, яка за жодних технологічних, економічних і соціальних умов розвитку ринку не повинна змінюватись (сутність + імідж бренду як точка його позиціювання на споживчому ринку). Інша частина образу бренду (атрибути + індивідуальність) повинна постійно трансформуватись як зворотна реакція на дії конкурентів і зміни макроекономічних чинників зовнішнього середовища (методи диференціації бренду від конкурентів).

По-друге, критерієм ефективності брендингової політики споживчих товарів $\epsilon$ охоплення збутової мережі та наявність певного бренду в роздрібних точках продажу, який для цільових регіонів повинен досягати $100 \%$. За умов різного ступеня лояльності споживачів (абсолютної, відносної, відсутньої) відносно продукції конкурентів рівень продажів буде зростати на фоні логістичних провалів з боку їх дистрибуції.

По-третє, головним інструментом брендингової політики споживчих товарів $\epsilon$ мерчандайзинг, серед складових якого важливе місце посідає візуальна складова як засіб виробника щодо позиціювання бренду на цільовому ринку (спрямований на ідентифікацію бренду з боку споживачів), а також як засіб привертання уваги та диференціації від конкурентів. На прикладі кольору етикеток та в залежності від структурних зрушень на ринку пива України визначено індекси популярності кольорів етикеток: помаранчевий, зелений, білий, чорний, червоний і синій (наведено за зниженням продажів), які можна використовувати при проведенні ребрендингу чи формування брендингової політики споживчих товарів для продуктових ринків.

\section{СПИСОК ВИКОРИСТАНИХ ДЖЕРЕЛ}

1. Стратегія міжнародної економічної діяльності кластерних утворень в інформаційній економіці: монографія /С.І. Гриценко, А.В. Таранич. - Донецьк: ДонНУ, 2010. - 227 с. 2. Таранич А. В., Балдэ К. Б. Нейромаркетинг - наука на стыке дисциплин [Електронний pecypc] - Режим доступу: http://www. rusnauka.com/13_EISN_2012/Economics/ 6_109803.doc.Htm.

3. Державний комітет статистики України [Електронний ресурс] - Режим доступу: http://www.ukrstat.gov.ua (дата звернення: 15.12.2018). - Назва з екрана.

4. Офіційний сайт ЗАТ «Укрпиво» [Електронний ресурс] - Режим доступу: http://ukrpivo.com (дата звернення: 15.12.2018). - Назва з екрана. 
5. Анализ дизайна бутылок и этикеток для пива 2017 [Електронний ресурс] - Режим доступу: https://koloro.ua/blog/dizain/analiz-dizajna-butylok-i-jetiketok-dlya-piva.html (дата звернення: 15.12.2018). - Назва з екрана.

6. Полторацкая А. Пивной рынок Украины: итоги 2017 [Електронний ресурс] - Режим доступу: https://koloro.ua/blog/issledovaniya/pivnoy-rynok-ukrainy-itogi-2017.html (дата звернення: 17.12.2018). - Назва з екрана. 